\title{
UNIVERSITYOF
}

FORWARD

THINKING

WESTMINSTER用

WestminsterResearch

http://www.westminster.ac.uk/westminsterresearch

'Does country-of-origin matter in the era of globalisation?

Evidence from cross sectional data in Uzbekistan

Karimov, F. and El-Murad, J.

This article is ( ) Emerald and permission has been granted for this version to appear here: http://westminsterresearch.westminster.ac.uk/

Emerald does not grant permission for this article to be further copied/distributed or hosted elsewhere without the express permission from Emerald Group Publishing Limited.

The final, published version in International Journal of Retail \& Distribution Management, 47 (3), pp. 262-277, 2019 is available at:

https://dx.doi.org/10.1108/IJRDM-06-2017-0129

The WestminsterResearch online digital archive at the University of Westminster aims to make the research output of the University available to a wider audience. Copyright and Moral Rights remain with the authors and/or copyright owners.

Whilst further distribution of specific materials from within this archive is forbidden, you may freely distribute the URL of WestminsterResearch: ((http://westminsterresearch.wmin.ac.uk/)).

In case of abuse or copyright appearing without permission e-mail repository@westminster.ac.uk 
emerald International Journal of Retail \& Distribution Management
PUBLISHING

\section{Does country-of-origin matter in the era of globalisation? Evidence from cross sectional data in Uzbekistan}

\begin{tabular}{|r|l|}
\hline Journal: & International Journal of Retail \& Distribution Management \\
\hline Manuscript ID & IJRDM-06-2017-0129.R5 \\
\hline Manuscript Type: & Research Paper \\
\hline Keywords: & $\begin{array}{l}\text { Country of origin, country image, made in, branding, Central Asia, } \\
\text { transitional country }\end{array}$ \\
\hline \multicolumn{2}{|l}{} \\
\hline
\end{tabular}

SCHOLARONE $^{\text {M }}$
Manuscripts 


\title{
Does country-of-origin matter in the era of globalisation? Evidence from cross sectional data in Uzbekistan
}

\begin{abstract}
Purpose: To examine the consistency over time of customer attitude towards country-of-origin in a transitional economy.

Design/methodology/approach: A single cross-sectional study in Uzbekistan was carried out, with $\mathrm{n}=527$, consisting of 374 street and 153 online surveys, replicating a study carried out 20 years earlier.

Findings: Whilst consumers still perceive products from advanced countries to have higher quality, quality perception in relation to country-of-origin information is dynamic, and transitional countries can improve the perception of consumers towards their national brands.

Research limitations/implications: This study was carried out in Tashkent, the capital of Uzbekistan, the most populous of the Central Asian republics. Researchers may wish to extend it by examining COO effects in other transitional economies, and additionally to examine the effect of country-of-brand origin.

Practical implications: Customer perceptions and attitudes take a long time to evolve. This crosssectional study showed the COO perception of China has improved significantly and the perception towards products produced locally in Uzbekistan has also slightly improved across all categories. Since strong brands may contribute to the image of the country, transitional countries need to take appropriate marketing actions to cultivate positive perception through innovation and branding.

Originality/value: Prior research has been extended by adding new product categories such as mobile phones, computers, washing machines and air conditioners. This research shows that government officials and exporters in developing countries should prioritise strengthening their country's image to help domestic marketers export and attract foreign investors. We provide insights for marketers to understand the impact of product country-of-origin on customer purchase intention and its antecedents in transitional economies such as Uzbekistan.
\end{abstract}

Keywords: Country of origin, country image, made in, branding, transitional country, Uzbekistan, Central Asia

Paper type: Research paper

\section{Introduction}

Much has been published about country of origin (COO) effects on consumer decision making (see, for example, Verlegh et al., 2005, Usunier, 2006, Bloemer et al., 2009). However, in the last 20 years globalisation has resulted in internationally integrated value chains, making it difficult for customers to trace the COO of products. For example, a shirt being sold, by a large retailer in the United States could be produced by a company headquartered in China. Later, through investigation, a customer may find it was designed in Italy, produced in Vietnam with textile from Bangladesh and buttons from Japan. On the demand side, a global customer can review user-generated comments about the quality of products and share information online. As these significant changes occur in international markets, researchers have questioned the salience of COO information in shaping brand or product evaluations (Alexander et al., 2010). A country's image may change over time: it is apparent, for example, that China is in the process of shedding its former image as a source of cheap imitation products (Schniederjans et al., 2011), yet little research has been done on the dynamic nature of COO effects. One exception was Lampert and Jaffe (1998), citing the example of Japan. Does COO still play an important role in the customer's decisionmaking process? Does "Made in..." matter anymore in the current era of globalisation?

The present study addresses these questions and contributes two-fold. Firstly, empirical studies on consumer behaviour in former soviet republics are in short supply. This study provides valuable insights for Western brands seeking to extend their market share in countries, which have only recently started to embrace economic and political liberalisation. A transitional economy, Uzbekistan, is the most populous of Central Asia's ex-Soviet republics and the only one bordering (and thus likely to influence) all the others. There is a small but growing body of literature about consumer behaviour in transitional economies, but few directly address COO. One exception is Barbu (2011) who was interested in the 
meaning for Romanian consumers of "Made in Romania", and (2016), in the role of expatriate Romanians as brand ambassadors for Romanian brands in their host countries. Coulter et al. (2005) studied the evolution of consumer knowledge and sources of consumer information about cosmetics in the transitional economy of Hungary but did not consider COO effects; Money and Colton (2000) looked specifically at transitional economies but only to study the effect of promotion. Secondly, studies which determine how COO perceptions may change over time have been notably absent (Lu et al., 2016). Zain and Yasin (1997) was used as a base for the current study to assess the extent to which COO effects are dynamic rather than static. By replicating their work in the original market (Uzbekistan), the extent to which consumer consideration of COO may have changed can be shown. For this purpose, Uzbekistan has the advantage of being a double land-locked and therefore relatively isolated market, until recently less susceptible to external influences, enabling a genuine comparison in spite of the twenty-year interval. The opportunity was taken to add several new product categories not commonly available or affordable for a typical customer 20 years ago in these countries; as well as providing insights into these new categories and better representing current consumer needs this will aid researchers looking to replicate the study in other countries or in the future. The paper starts with a review of the theoretical developments in $\mathrm{COO}$ research. A set of hypotheses concerning the influence of $\mathrm{COO}$ information on the customer decision-making process is then developed, and the methodology discussed. Finally, empirical results are presented and discussed concluding with implications for managers and future research.

\section{Theoretical background and hypotheses The importance of $\mathrm{COO}$ in consumer product evaluation}

The effect of $\mathrm{COO}$, where products are produced or assembled, on buyer perceptions and product attitudes and evaluations is a hot topic in the international business, marketing and consumer behaviour literature. Although a significant amount of scholarly work has been published on the subject over the last fifty years, there has been increasing debate and little consensus over its conceptualization and its importance (Alexander et al., 2010; Samiee et al., 2016). Several studies report a positive COO influence on buyers' evaluations and choices (Kalicharan, 2014), and that the "Made In..." label is (still) a key extrinsic cue directly influencing consumers' preferences (Cui et al., 2014), and effectively used to develop positioning strategies by international marketers. Consider Volkswagen's "German engineered road sedans", for example, or this advertisement by a former South Korean carmaker: "Who gives you Italian style, British handling and German engineering? Daewoo, that's who." (Papadopoulos et al, 2000, pp.1).

Decades of research have led to one conclusion: the $\mathrm{COO}$ of a product can influence customers' evaluative judgments of it (Kan, 2016). Only within recent years has this conclusion been called into question. Usunier (2011) claims that COO information based on "Made-in" labels is no longer relevant in international marketing. Global sourcing, universal branding strategies, and advancements in international trade regulations create confusion over product origins making them more ambiguous and difficult for customers to ascertain. Jeong et al. (2012) explored the case of dietary supplements in China, finding no significant $\mathrm{COO}$ effect on customer attitudes and behavioural intention. Their explanation is that whilst China may be a transitional economy, it is also a major manufacturing source for foreign products, including the US. COO is a confusing, as consumers may not perceive foreign products as different from domestic versions, even if imported. This Chinese example does not extend to all transitional economies: Barbu (2016) found that while expatriate Romanians showed appreciation for their home country brands their intention to buy remained low. In general, however, manufacturing $\mathrm{COO}$ has become largely irrelevant; brands have now taken the lead in communicating product quality (Aichner et al., 2016). Magnusson et al (2011) empirically confirm that consumers' perceived country of brand origin strongly affects their brand attitudes. They suggest educating consumers about brands' true COO can contribute to changes in brand attitudes, as consumers often do not know the true origin of many even well-known brands, frequently assigning a brand to the wrong country (Balabanis, 2011). In this respect, Wu and Fu (2007) reveal that "made-in" cues have significant impact on quality evaluation while brand origin cues 
influence purchase intention: under conditions of low brand familiarity a product's origin is still a determinant cue (Johnson et al., 2016; Koschate-Fischer et al., 2012).

The 2013 'horsemeat scandal' revealed that the origin and type of meat in food products had been incorrectly marketed, lacking transparency and misleading consumers (Balcombe et al., 2016; Tse et al., 2016). This caused the introduction of new EU food labelling regulations giving increased emphasis to COO labelling (Agnoli et al., 2016). All packaged products must now indicate the country or countries of origin of all production stages. This suggests that manufacturing origin is more than ever an expression of quality and is crucial information for the customer: the suggestion that $\mathrm{COO}$ has become irrelevant in international marketing may be premature.

The COO effect is defined as the "extent to which the place of manufacture influences consumer evaluations and product-related decisions" (Kabadayi \& Lerman, 2011, pp. 104). COO may affect consumer behaviour in three ways: signalling the quality of products, acting as an independent cue in product evaluation and simplifying the product evaluation process (Ahmed et al., 2004). Recently published studies confirm that COO information still has a significant influence on buyers' evaluation, choice of products, and willingness to pay (Andéhn \& Decosta, 2016; Insch \& Florek, 2009; Kalicharan, 2014; Koschate-Fischer et al., 2012). Since it is difficult to compare multiple product characteristics (performance, price, prestige, reliability, etc.) customers consider COO information a major extrinsic cue for assessing product quality ( $\mathrm{Lu}$ et al., 2016). Based on this discussion it is proposed that:

\section{H1: The COO of a product has a significant influence on buyer perceptions and attitude towards the product.}

COO and demographic variables

Although Zain and Yasin (op. cit.) found no statistically significant demographic differences in the level of importance consumers give to COO, other researchers did (e.g. Diallo et al., 2016; Loureiro \& Umberger 2003; Samiee, 1994). Age, education, gender, and perceptions of ability to judge products are related to consumers' ratings of quality, risk, value and purchase intent, especially when the product is complex (Wall et al., 1991). Attitudes towards COO vary with consumers' age, marital status, family lifecycle stage, income and education (Ahmed \& d'Astous 2008); more educated, higher income consumers accept foreign products more readily (Niss, 1996), both younger and upper-class consumers show a lower level of prejudice towards products originating from less-developed countries (Leonidou et al., 1999). Several authors found that younger, wealthier and more educated consumers evaluate foreign products more favourably (Ahmed \& d'Astous, 2002), as do women (Loureiro \& Umberger, 2003), whilst older people tend to evaluate foreign products more carefully (Smith, 2014). In the view of this discussion, it is proposed that:

\section{H2: Attitude towards COO is related to consumers' (a) gender, (b) age, (c) marital status, (d) income and (e) education.}

\section{COO and level of economic development}

Country image is multi-dimensional and $\mathrm{COO}$ effects are complex. Influenced by performance inferences based on the level of economic development and consumer ethnocentrism (Cagé \& Rouzet, 2015; Huddleston, 2001; Maheswaran et al., 2013), the more developed the country, the more positive the attitude towards products manufactured there (Rezvani et al., 2012). Consumers typically view foreign products from developed countries more favourably (Samiee, 1994), are often prejudiced against products from less developed countries (Nagashima, 1977; Maheswaran et al., 2013), and in developed countries prefer products from their own country first, then products from other developed countries before products from less developed countries (Ahmed et al., 2004). Kaynak and Kara (2002) suggest considering $\mathrm{COO}$ information for segmentation and targeting, with products from more developed countries targeted at high income segments. Based on this logic, it is predicted that: 
H3: The perceived quality of products manufactured in developed countries is higher than that of products manufactured in developing countries.

The dynamic rather than static nature of country image

Several studies confirm that country image may change over time and is specific to the context (e.g. Dinnie, 2004; Jones, 2010; Kumar, 2009). Nagashima (1970) empirically confirmed that the perceived cross-cultural image of "made in..." stereotypes differed between Japanese and U.S. businessmen. In his follow-up longitudinal study, Nagashima (1977) measured whether changes had taken place in evaluation of the "made in" image of products, finding that the overall image of products made in Japan, Germany, Britain and France had improved whereas the overall "made in the USA" image had deteriorated. Papadopoulos et al (1990) also found that country image can change over time, at least in the long term. The research about $\mathrm{COO}$ confirms that country image can be enhanced, and perceptions altered. Based on this discussion, the following is proposed:

\section{H4. Perceived quality of products in relation to COO may change over time.}

The outcome variables investigated in the proposed hypotheses such as buyer perceptions, product evaluations, and perceived qualities can be defined as follows. In this context, buyer perception is the customer's impression about a brand or a company or its offerings. Evaluation means that product's suitability for use by customers is assessed. Perceived quality can be defined as the customer's perception of the overall quality or superiority of a product relative to alternatives.

\section{Methodology}

\section{Data collection, subjects and measures}

Four focus groups were conducted separately, two for male, and two for female participants. Each included eight people (university instructors and/or graduate students); trained research assistants moderated the process. Open-ended questions were used to identify product categories participants sought country-of-origin information for the most. Zain and Yasin's (1997) questionnaire included eight products (cars, dresses/shirts, pants, shoes, cameras, television, refrigerator, and radio) and seven countries (Russia, Turkey, USA, China, Japan, India, and Uzbekistan). Based on focus group findings we extended Zain and Yasin's questionnaire, adding mobile phones, computers, washing machines and air conditioners, none of which were widely available in 1997. The list of countries was also extended adding South Korea, UK, Germany, Spain and Italy.

The 13 statements forming Section A of the questionnaire (Table 2) were from Zain and Yasin's study (op.cit.) and measured the importance customers placed on COO. All items used five-point Likert-type scales $(5=$ strongly agree; $4=$ agree; $3=$ neither agree nor disagree; $2=$ disagree; and $1=$ strongly disagree) and were adopted from recent literature where they were repeatedly shown to exhibit strong content validity (ibid). Section B sought respondents' evaluation of the quality of specific products made in particular countries: "Please evaluate (rate) the quality of products manufactured in the following countries" (see Table 5). A five-point Likert-type scale was used for quality evaluations of each product category from each country; all identified in the focus groups. The final section of the questionnaire collected respondent demographics.

Data were collected in personal street surveys by distributing 400 printed questionnaires (in both Uzbek and Russian) randomly in Tashkent. Google Forms was used for an online survey with the link shared via social network among local "sample". 527 cases were completed, of which 374 were street surveys and 153 online. Table 1 shows descriptive statistics for respondents. 271 (51.4\%) were male, most were aged between 18 and $25(62.8 \%)$. 
According to the State Committee of the Republic of Uzbekistan 57.2\% of the population is below 29 years of age (https://gender.stat.uz). The largest age group is adolescents, as reflected by this sample; a large proportion of these are students $(53.9 \%)$. The use of student data is acceptable when it is corroborated with comparable non-student samples (Bello et al., 2009); studies designed to assess crossculturally life stage or generational differences and those that explore differences in views and values within countries and cultures benefit by including student data, moreover it would not have been possible to exclude students without excluding a major age segment of the population of Uzbekistan.

Table 1. Respondent Descriptive Statistics

\begin{tabular}{|c|c|c|c|c|c|c|c|}
\hline & 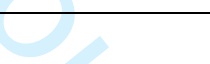 & Frequency & Percent & & & Frequency & Percent \\
\hline \multirow{2}{*}{ Gender } & female & 256 & 48.6 & \multirow{7}{*}{ Occupation } & \multirow{7}{*}{$\begin{array}{l}\text { student } \\
\text { housewife } \\
\text { private sector } \\
\text { public sector } \\
\text { self-employed } \\
\text { unemployed } \\
\text { retired }\end{array}$} & 284 & 53.9 \\
\hline & male & 271 & 51.4 & & & 18 & 3.4 \\
\hline \multirow{5}{*}{ Age } & age $18-25$ & 331 & 62.8 & & & 91 & 17.3 \\
\hline & age $26-35$ & 80 & 15.2 & & & 83 & 15.7 \\
\hline & age $36-45$ & 54 & 10.2 & & & 12 & 2.3 \\
\hline & age $46-55$ & 22 & 4.2 & & & 7 & 1.3 \\
\hline & age 55-older & & 7.6 & & & 32 & 6.1 \\
\hline \multirow{3}{*}{$\begin{array}{l}\text { Marital } \\
\text { status }\end{array}$} & single & 355 & 67.4 & \multirow{7}{*}{$\begin{array}{l}\text { Income* in } \\
\text { Million } \\
\text { Uzbekistan } \\
\text { Soum } \\
\text { (UzSoum) }\end{array}$} & up to 1 & 218 & 41.4 \\
\hline & married & 158 & 30 & & $1-2$ & 149 & 28.3 \\
\hline & divorced & 14 & 2.7 & & $2-3$ & 44 & 8.3 \\
\hline \multirow{4}{*}{ Education } & \multirow{2}{*}{$\begin{array}{l}\text { secondary } \\
\text { higher }\end{array}$} & 129 & 24.5 & & \multirow{3}{*}{$\begin{array}{l}3-4 \\
4 \text { - } 5 \\
\text { above } 5\end{array}$} & 49 & 9.3 \\
\hline & & 398 & 75.5 & & & 21 & 4 \\
\hline & & & - & & & 46 & 8.7 \\
\hline & & & & & Total & 527 & 100 \\
\hline
\end{tabular}

\section{Results}

\section{Respondents' use of COO information}

The mean scores for each statement were calculated and compared, in Table 2, to Zain and Yasin's findings (op. cit.). In 2016, respondents considered manufacturing COO information to be the most important cue when purchasing expensive items such as cars, TVs or refrigerators (4.46), when checking the quality of the product (4.29), and when deciding which product to buy (4.08). On the other hand, when buying cheaper goods, such as a shirt, they considered it to be less important - a mean score of 3.54 and 3.23 (statements 5 and 13 in Table 2). This supports H1 that Uzbek consumers still consider COO information a vital cue when purchasing relatively expensive products. Consumers also refer to COO information when buying products higher in symbolic value such as a dress (3.95), and products that have a high risk of malfunctioning (4.07) such as a watch. The corresponding mean values are slightly higher in the current study than in Zain and Yasin's findings but are consistent with them.

Six of the 13 items scored higher than in 1997, suggesting that for these the COO effect may actually be stronger. Three are almost identical, suggesting no change, four are lower. However, the biggest changes are for items 9 "When I am buying a new product..." (-11.5\%), and 5 "(COO)... is less important for cheap goods than for expensive goods" (-9.5\%), and 2 "To make sure that I buy the highest quality..." (7.3\%). It seems that today's Uzbek customers rely less on $\mathrm{COO}$ when buying a new product, agree more strongly than 20 years ago that $\mathrm{COO}$ is less important for less expensive products, and agree more strongly than in 1997 that COO matters for goods of the highest quality.

Mean scores are lower for item 10 "To buy a product that is acceptable to my friends and my family...": (3.52 vs. 3.69) than in Zain and Yasin (ibid). Lascu and Babb (1995), who studied Polish customers, also found lower mean scores for these two statements: 2.95 and 2.98 respectively. Zain and Yasin explained that "although Polish consumers need COO information in making their purchase decisions, it is, to a 
great extent, not a piece of information they seek first when considering the purchase of a new product or a product that is acceptable to family and friends" (pp. 142). In this regard it could also be argued that today "COO information" may not be the only information Uzbek customers seek when buying products. Since 1997 improved Internet access and affordable mobile communication have allowed Uzbek customers to read product information online, markets have become more open towards world trade, and the entry of global brands has shaped consumer culture.

Table 2. Country-of-origin information of products

\begin{tabular}{|c|c|c|c|c|}
\hline & & Mean scores & & \\
\hline & & $\begin{array}{l}\text { Present } \\
\text { study - } \\
\text { Uzbekistan } \\
\text { (2016) }\end{array}$ & $\begin{array}{l}\text { Zain and } \\
\text { Yasin's } \\
\text { study- } \\
\text { Uzbekistan } \\
\text { (1997) }\end{array}$ & $\begin{array}{l}\text { Lascu and } \\
\text { Babb's } \\
\text { study } \\
\text { Poland } \\
\text { (1995) }\end{array}$ \\
\hline 1 & $\begin{array}{l}\text { When buying an expensive item, such as a car, TV or } \\
\text { refrigerator I always seek to find out what country the } \\
\text { product was made in }\end{array}$ & 4.46 & 4.35 & 4.16 \\
\hline 2 & $\begin{array}{l}\text { To make sure that I buy the highest quality product or brand, } \\
\text { I look to see what country the product was made in }\end{array}$ & 4.29 & 4.00 & 3.55 \\
\hline 3 & $\begin{array}{l}\text { I feel that it is important to look for country-of-origin } \\
\text { information when deciding which product to buy }\end{array}$ & 4.08 & 3.95 & 3.36 \\
\hline 4 & I look for the "Made in ..." labels in clothing & 3.95 & 3.94 & 3.39 \\
\hline 5 & $\begin{array}{l}\text { Seeking country-of-origin information is less important for } \\
\text { inexpensive goods than for expensive goods }\end{array}$ & 3.54 & 3.91 & 3.61 \\
\hline 6 & $\begin{array}{l}\text { A person should seek country-of-origin information when } \\
\text { buying a product with a fairly low risk of malfunctioning, e.g. } \\
\text { when buying shoes }\end{array}$ & 3.54 & 3.54 & 3.95 \\
\hline 7 & $\begin{array}{l}\text { I look for country-of-origin information to choose the best } \\
\text { product available in a product class }\end{array}$ & 3.71 & 3.86 & 3.15 \\
\hline 8 & $\begin{array}{l}\text { I find out a product's country of origin to determine the } \\
\text { quality of the product }\end{array}$ & 3.82 & 3.77 & 3.22 \\
\hline 9 & $\begin{array}{l}\text { When I am buying a new product, the country of origin is the } \\
\text { first piece of information that I consider }\end{array}$ & 3.31 & 3.74 & 2.95 \\
\hline 10 & $\begin{array}{l}\text { To buy a product that is acceptable to my friends and my } \\
\text { family, I look for the product's country of origin }\end{array}$ & 3.52 & 3.69 & 2.98 \\
\hline 11 & $\begin{array}{l}\text { If I have little experience with a product, I search for } \\
\text { country-of-origin information about the product to help me } \\
\text { make a more informed decision }\end{array}$ & 3.64 & 0 & 3.38 \\
\hline 12 & $\begin{array}{l}\text { A person should always look for country-of-origin } \\
\text { information when buying a product that has a high risk of } \\
\text { malfunctioning, e.g. when buying a watch (computer) }\end{array}$ & 4.07 & 3.88 & 3.98 \\
\hline 13 & $\begin{array}{l}\text { When buying a product that is less expensive, such as a shirt, } \\
\text { it is less important to look for the country of origin }\end{array}$ & 3.23 & 3.08 & 3.60 \\
\hline
\end{tabular}

Note: Statements were rated on a scale of 1-5

\section{The relationship between COO dimensions and demographic variables}

Factor analysis was used to determine the main items (Table 3), using the principal component method with varimax rotation; factor loadings for all items were above 0.50 . Bartlett's test of sphericity is highly significant $(p<0.001)$ and the Kaiser-Meyer-Olkin measure of sampling adequacy indicated that the strength of the relationships among variables was high $(\mathrm{KMO}=0.899)$, rendering factor analysis meaningful for this dataset. 
Three factors explained $43.5 \%$ of the variance. Following Zain and Yasin (1997), we labelled factor 1 Social-Assurers (people who give much credence to other people's opinions), factor 2 Security-Seekers (people who check for quality), and factor 3 Price-Vetters (people who check for price). Cronbach's alpha was used to assess the reliability of the measures. The Social-Assurers' subscale of eight items had internal consistency reliability of $\alpha=0.882$, the Security-Seekers' subscale of three items had reliability of $\alpha=0.765$, and Price-Vetters subscale (two items) a reliability of $\alpha=0.585$. A reliability coefficient of 0.60 or larger is acceptable (Nunnally, 1976). Although factor 3 reliability is low, the factor coefficients of the items are highly polarized (see Table 3 ).

Table 3. Factor analysis of the importance of country-of-origin information

\begin{tabular}{|c|c|c|c|}
\hline \multirow{3}{*}{ Construct items } & \multirow{2}{*}{\multicolumn{3}{|c|}{ Component }} \\
\hline & & & \\
\hline & 1 & 2 & 3 \\
\hline \multicolumn{4}{|l|}{ Social-Assurers } \\
\hline $\begin{array}{l}\text { 1. To buy a product that is acceptable to my friends and my family, I look for } \\
\text { the product's country of origin }\end{array}$ & 0.789 & 0.312 & -0.005 \\
\hline $\begin{array}{l}\text { 2. If I have little experience with a product, I search for country-of-origin } \\
\text { information about the product to help me make a more informed decision }\end{array}$ & 0.751 & 0.117 & 0.216 \\
\hline $\begin{array}{l}\text { 3. When I am buying a new product, the country of origin is the first piece of } \\
\text { information that I consider }\end{array}$ & 0.728 & 0.281 & 0.119 \\
\hline $\begin{array}{l}\text { 4. I look for country-of-origin information to choose the best product } \\
\text { available in a product class }\end{array}$ & 0.689 & 0.242 & 0.247 \\
\hline $\begin{array}{l}\text { 5. I find out a product's country of origin to determine the quality of the } \\
\text { product }\end{array}$ & 0.674 & 0.325 & 0.066 \\
\hline $\begin{array}{l}\text { 6. A person should seek country-of-origin information when buying a } \\
\text { product with a fairly low risk of malfunctioning, e.g. when buying shoes }\end{array}$ & 0.671 & 0.050 & 0.136 \\
\hline 7. I look for the "Made in ..." labels in clothing & 0.649 & 0.346 & -0.129 \\
\hline $\begin{array}{l}\text { 8. A person should always look for country-of-origin information when } \\
\text { buying a product that has a high risk of malfunctioning, e.g. when buying a } \\
\text { watch }\end{array}$ & 0.588 & 0.250 & 0.106 \\
\hline \multicolumn{4}{|l|}{ Security-Seekers } \\
\hline $\begin{array}{l}\text { 9. To make sure that I buy the highest quality product or brand, I look to see } \\
\text { what country the product was made in }\end{array}$ & 0.328 & 0.792 & 0.071 \\
\hline $\begin{array}{l}\text { 10. I feel that it is important to look for country-of-origin information when } \\
\text { deciding which product to buy }\end{array}$ & 0.385 & 0.737 & -0.017 \\
\hline $\begin{array}{l}\text { 11. When buying an expensive item, such as a car, TV or refrigerator I always } \\
\text { seek to find out what country the product was made in }\end{array}$ & 0.154 & 0.737 & 0.180 \\
\hline \multicolumn{4}{|l|}{ Price-Vetters } \\
\hline $\begin{array}{l}\text { 12. Seeking country-of-origin information is less important for inexpensive } \\
\text { goods than for expensive goods }\end{array}$ & 0.022 & 0.223 & 0.827 \\
\hline $\begin{array}{l}\text { 13. When buying a product that is less expensive, such as a shirt, it is less } \\
\text { important to look for the country of origin }\end{array}$ & & -0.048 & 0.787 \\
\hline Cronbach's $\alpha$ & 0.882 & 0.765 & 0.585 \\
\hline Eigenvalues & 5.651 & 1.320 & 1.054 \\
\hline Eigenvalue \% of Variance & 32.359 & 17.725 & 11.645 \\
\hline \multicolumn{4}{|l|}{$\begin{array}{l}\text { Extraction Method: Principal Component Analysis. } \\
\text { Rotation Method: Varimax with Kaiser Normalization. }{ }^{\text {a }} \\
\text { a. Rotation converged in } 6 \text { iterations. }\end{array}$} \\
\hline
\end{tabular}

Hypothesis 2, that there would be a relationship between consumers' COO evaluations and demographic variables (a) gender (b) age (c) marital status (d) income and (e) education, was tested by analysis of variance (ANOVA) (see Table 4). 
For gender, results were statistically significant for Social-Assurers with women $(\mathrm{M}=0.165 ; \mathrm{SD}=0.947)$ scoring higher than men $(\mathrm{M}=-0.156 ; \mathrm{SD}=1.024)$, and for Price-Vetters, with women less concerned about price $(\mathrm{M}=-0.129 ; \mathrm{SD}=1.049)$ than men $(\mathrm{M}=0.122 ; \mathrm{SD}=0.936)$. There was no significant gender difference for Security-Seekers.

\begin{tabular}{|c|c|c|c|c|c|c|}
\hline \multirow[b]{2}{*}{$\begin{array}{l}\text { Demographic } \\
\text { variables }\end{array}$} & & \multicolumn{3}{|c|}{$\begin{array}{l}\text { Country-of-origin information } \\
\text { importance dimensions }\end{array}$} & \multirow[b]{2}{*}{$\begin{array}{c}\text { Roy's } \\
\text { largest root } \\
\text { (Value) }\end{array}$} & \multirow[b]{2}{*}{$\begin{array}{c}\text { Wilks' } \\
\text { Lambda } \\
\text { (Value) }\end{array}$} \\
\hline & & $\begin{array}{c}\text { Social- } \\
\text { Assurers }\end{array}$ & $\begin{array}{l}\text { Security- } \\
\text { Seekers }\end{array}$ & $\begin{array}{c}\text { Price- } \\
\text { Vetters }\end{array}$ & & \\
\hline \multirow[t]{2}{*}{ Gender } & $\mathrm{F}$ & 13.89 & 2.35 & 8.43 & .048 & .954 \\
\hline & sig. & $(.000)$ & $(.126)$ & $(.004)$ & $(.000)$ & $(.000)$ \\
\hline \multirow[t]{2}{*}{ Age } & $\mathrm{F}$ & 8.92 & 6.53 & 12.15 & .202 & .808 \\
\hline & sig. & $(.000)$ & $(.000)$ & $(.000)$ & $(.000)$ & $(.000)$ \\
\hline \multirow[t]{2}{*}{ Marital status } & $\mathrm{F}$ & 6.15 & .911 & 8.62 & .060 & .942 \\
\hline & sig. & $(.002)$ & $(.403)$ & $(.000)$ & $(.000)$ & $(.000)$ \\
\hline \multirow[t]{2}{*}{ Education } & $\mathrm{F}$ & 3.13 & 1.39 & .002 & .009 & .991 \\
\hline & sig. & $(.078)$ & $(.239)$ & $(.965)$ & $(.212)$ & $(.212)$ \\
\hline \multirow[t]{2}{*}{ Occupation } & $\mathrm{F}$ & 2.82 & 4.03 & 8.61 & .143 & .839 \\
\hline & sig. & $(.010)$ & $(.001)$ & $(.000)$ & $(.000)$ & $(.000)$ \\
\hline \multirow[t]{2}{*}{ Income } & $\mathrm{F}$ & 2.35 & 5.09 & 3.44 & .059 & .902 \\
\hline & sig. & $(.040)$ & $(.000)$ & $(.005)$ & $(.000)$ & $(.000)$ \\
\hline
\end{tabular}

Age had a significant effect on Social-Assurers $(F=8.92, p<0.001)$, Security-Seekers $(F=6.53, p<0.001)$, and Price-Vetters $(\mathrm{F}=12.15, \mathrm{p}<0.001)$. The mean plots for the Security-Seeking dimension increase with age $\left(\mathrm{M}=-0.180_{\text {age }} 18-25\right.$ versus $\left.0.706_{\text {age }} 46-55\right)$, while Social-Assurance and Price-Vetting peak between ages 46 and 55. Pairwise comparisons and post hoc Bonferroni tests show this effect to be highly significant with the mean differences for Social-Assurers $(M=-0.549 ; \mathrm{p}<0.008)$, Security-Seekers $(M=0.698$; $\mathrm{p}<0.001)$ and Price-Vetters $(\mathrm{M}=0.971 ; \mathrm{p}<0.001)$.

Table 4 shows significant COO differences for marital status, occupation, and income. More SocialAssurers are married than single $\left(\mathrm{M}=0.220_{\text {married }}, \mathrm{SD}=0.872\right.$ versus $\left.\mathrm{M}=-0.105_{\text {single }}, \mathrm{SD}=1.044, \mathrm{p}<0.002\right)$; a post hoc Bonferroni test shows this effect to be highly significant with the mean difference $(\mathrm{M}=0.325$, $\mathrm{p}<0.002)$. While we did not find any statistical significance for Security-Seekers, more Price-Vetters were married than single $\left(\mathrm{M}=0.220_{\text {married }}, \mathrm{SD}=0.872\right.$ versus $\left.\mathrm{M}=-0.105_{\text {single, }}, \mathrm{SD}=1.044\right)$.

Although the mean plots demonstrate that respondents with lower education are more sensitive to all $\mathrm{COO}$ information factors, the results were not statistically significant and H2(e) is not supported, in line with Zain and Yasin's (1997) findings.

ANOVA revealed significant differences in COO dimensions between occupations. Descriptive results show that a higher proportion of retired people $(\mathrm{M}=0.621, \mathrm{SD}=0.582)$ are Security-Seekers compared to housewives $(\mathrm{M}=-0.588, \mathrm{SD}=0.232)$ and students $(\mathrm{M}=-0.097, \mathrm{SD}=0.058)$; this was supported by a post hoc Bonferroni test. Post hoc Bonferroni tests additionally suggested that employed people are more price sensitive than students and the unemployed. Private sector vs. students (mean difference: $M=0.664$, $\mathrm{p}<0.001$ ), public sector vs. students (mean difference: $\mathrm{M}=0.479, \mathrm{p}<0.001$ ) and unemployed (mean difference: $\mathrm{M}=1.473, \mathrm{p}<0.002$ ), and self-employed vs. unemployed (mean difference: $\mathrm{M}=1.448$, 
$\mathrm{p}<0.033$ ). This may be partially explained by the fact that in Uzbekistan all students receive a government stipend, and (officially) unemployed people are often involved in "business", consequently wealthier than salaried employees; an alternative interpretation is that people who earn money are more discerning about spending it. There is no significant difference between retired people and the unemployed (mean difference: $\mathrm{M}=1.154, \mathrm{p}<0.086)$.

Income has a significant effect on all $\mathrm{COO}$ dimensions, which tend to reduce the higher the income. A post hoc Bonferroni test regarding Security-Seekers reveals no difference between the groups whose earnings are up to UzS3m. A statistically significant difference exists between those earning up to $1 \mathrm{~m}$ and $3-4 \mathrm{~m}$ (mean difference: $\mathrm{M}=0.485, \mathrm{p}<0.028$ ), and 4-5m (mean difference: $\mathrm{M}=0.814, \mathrm{p}<0.005$ ). People who earn $1-2 \mathrm{~m}$ differ from those who earn $3-4$ or $4-5 \mathrm{~m}$ (mean difference: $\mathrm{M}=0.556, \mathrm{p}<0.009$; or $\mathrm{M}=0.885$, $\mathrm{p}<0.002$ ). The same is observed for those who earn $2-3 \mathrm{~m}$ and $4-5 \mathrm{~m}$ (mean difference: $\mathrm{M}=0.819$, $\mathrm{p}<0.026$ ): fewer higher earners are Security-Seekers in relation to COO, whilst households with earnings above UzS5m per month (\$637) are more Price-Vetters compared to those who earn up to $1 \mathrm{~m}(\mathrm{M}=0.364$, $\mathrm{SD}=0.711$ versus $\mathrm{M}=-0.128, \mathrm{SD}=0.952$ ). A post hoc Bonferroni test confirms this significance (mean difference: $\mathrm{M}=0.491, \mathrm{p}<0.035$ ).

\section{Perceived quality of products based on the country-of-origin, and the dynamic nature of COO perceptions}

Hypothesis 3 is that perceived quality of products manufactured in developed countries is higher than that of products manufactured in developing countries, and Table 5 shows the mean scores and overall rankings for 2017, supporting H3 by revealing that products from countries like Germany, Japan, the USA, S.Korea and UK are believed to be of higher quality than those from countries like India, Uzbekistan and China. This is in line with Zain and Yasin's findings (op.cit.). In the overall ranking, Germany was perceived as producing the highest quality, with Japan second followed by the USA and South Korea. Japan received the highest score for eight of twelve product categories, Italy for three of the remaining four with Germany leading only in one (cars).

Table 5. Perceived quality of products made in specific countries (2017)

\begin{tabular}{|c|c|c|c|c|c|c|c|c|c|c|c|c|}
\hline Products & Germany & Japan & USA & S.Korea & UK & Italy & Spain & Russia & China & Turkey & Uzbekistan & India \\
\hline Cars & 4.83 & 4.68 & 4.44 & 4.26 & 4.26 & 4.25 & 3.38 & 2.89 & 2.77 & 2.73 & 3.09 & 2.40 \\
\hline Dresses/shirts & 4.48 & 3.92 & 4.24 & 3.95 & 4.28 & 4.58 & 3.75 & 3.16 & 2.89 & 4.08 & 3.00 & 3.28 \\
\hline Pants & 4.43 & 3.92 & 4.17 & 3.90 & 4.23 & 4.57 & 3.74 & 3.12 & 2.89 & 4.03 & 2.98 & 3.20 \\
\hline Shoes & 4.47 & 3.87 & 4.20 & 3.85 & 4.27 & 4.58 & 3.75 & 3.21 & 2.76 & 3.87 & 2.69 & 2.96 \\
\hline Cameras & 4.58 & 4.68 & 4.39 & 4.35 & 4.04 & 3.61 & 3.30 & 2.97 & 3.05 & 2.77 & 2.40 & 2.64 \\
\hline Television & 4.55 & 4.68 & 4.26 & 4.40 & 4.05 & 3.55 & 3.29 & 3.09 & 3.11 & 2.77 & 2.82 & 2.56 \\
\hline Refrigerator & 4.59 & 4.65 & 4.17 & 4.37 & 4.02 & 3.61 & 3.31 & 3.47 & 3.05 & 2.78 & 2.75 & 2.52 \\
\hline Radio & 4.52 & 4.56 & 4.14 & 4.31 & 3.95 & 3.52 & 3.27 & 3.36 & 3.01 & 2.72 & 2.72 & 2.58 \\
\hline Mobile phones & 4.46 & 4.56 & 4.47 & 4.36 & 3.96 & 3.42 & 3.22 & 2.95 & 3.17 & 2.55 & 2.67 & 2.51 \\
\hline PC/laptops & 4.47 & 4.64 & 4.60 & 4.33 & 4.00 & 3.41 & 3.18 & 2.90 & 3.27 & 2.54 & 2.44 & 2.52 \\
\hline Washing machines & 4.59 & 4.60 & 4.34 & 4.35 & 3.99 & 3.48 & 3.19 & 3.17 & 3.10 & 2.64 & 2.60 & 2.42 \\
\hline Air conditioners & 4.57 & 4.60 & 4.33 & 4.36 & 3.98 & 3.46 & 3.18 & 3.12 & 3.14 & 2.67 & 2.68 & 2.49 \\
\hline COO average & 4.54 & 4.45 & 4.31 & 4.23 & 4.09 & 3.84 & 3.38 & 3.12 & 3.02 & 3.01 & 2.74 & 2.67 \\
\hline Overall ranking & 1 & 2 & 3 & 4 & 5 & 6 & 7 & 8 & 9 & 10 & 11 & 12 \\
\hline
\end{tabular}

H4 was that perceived quality of products in relation to COO may change over time. The comparison of mean scores for 1997 and 2017 is provided in Table 6, which omits the products and countries added in this study. Zain and Yasin (1997) did not include Germany, thus Japan was the first in their ranking. Cars, cameras, televisions, refrigerators and radios made in Japan were perceived to be of higher quality than those made in other countries included in the study, consistent with Zain and Yasin's findings. Zain and 
Yasin found China had the lowest overall ranking $(\mathrm{M}=2.33)$; it has now overtaken Uzbekistan and India; with the additional product, has also overtaken Turkey.

Table 6. Perceived quality of products made in specific countries

\begin{tabular}{|c|c|c|c|c|c|c|c|c|c|c|c|c|c|c|}
\hline \multirow{2}{*}{$\begin{array}{l}\text { Products/countries } \\
\text { Period of study }\end{array}$} & \multicolumn{2}{|c|}{ Japan } & \multicolumn{2}{|c|}{ USA } & \multicolumn{2}{|c|}{ Russia } & \multicolumn{2}{|c|}{ Turkey } & \multicolumn{2}{|c|}{ India } & \multicolumn{2}{|c|}{ Uzbekistan } & \multicolumn{2}{|c|}{ China } \\
\hline & 1997 & 2017 & 1997 & 2017 & 1997 & 2017 & 1997 & 2017 & 1997 & 2017 & 1997 & 2017 & 1997 & 2017 \\
\hline Cars & 4.82 & 4.68 & 4.64 & 4.44 & 3.35 & 2.89 & 2.92 & 2.73 & 2.16 & 2.40 & 2.32 & 3.09 & 2.21 & 2.77 \\
\hline Dresses/shirts & 4.28 & 3.92 & 4.55 & 4.24 & 3.14 & 3.16 & 3.18 & 4.08 & 2.98 & 3.28 & 2.46 & 3.00 & 2.34 & 2.89 \\
\hline Pants & 4.08 & 3.92 & 4.53 & 4.17 & 3.10 & 3.12 & 3.22 & 4.03 & 2.85 & 3.20 & 2.50 & 2.98 & 2.32 & 2.89 \\
\hline Shoes & 4.13 & 3.87 & 4.55 & 4.20 & 3.24 & 3.21 & 2.89 & 3.87 & 2.70 & 2.96 & 2.21 & 2.69 & 2.02 & 2.76 \\
\hline Cameras & 4.89 & 4.68 & 4.49 & 4.39 & 3.30 & 2.97 & 2.61 & 2.77 & 2.36 & 2.64 & 2.08 & 2.40 & 2.34 & 3.05 \\
\hline Television & 4.90 & 4.68 & 4.45 & 4.26 & 3.46 & 3.09 & 2.93 & 2.77 & 2.38 & 2.56 & 2.74 & 2.82 & 2.49 & 3.11 \\
\hline Refrigerator & 4.81 & 4.65 & 4.53 & 4.17 & 3.65 & 3.47 & 2.89 & 2.78 & 2.43 & 2.52 & 2.97 & 2.75 & 2.47 & 3.05 \\
\hline Radio & 4.85 & 4.56 & 4.42 & 4.14 & 3.72 & 3.36 & 2.81 & 2.72 & 2.47 & 2.58 & 2.67 & 2.72 & 2.46 & 3.01 \\
\hline $\begin{array}{l}\text { Country of origin } \\
\text { average }\end{array}$ & 4.60 & 4.37 & 4.52 & 4.25 & 3.3 & 3.16 & 2.93 & 3.22 & 2.54 & 2.77 & 2.49 & 2.80 & 2.33 & 2.94 \\
\hline Mean difference & \multicolumn{2}{|c|}{-0.23} & \multicolumn{2}{|c|}{-0.27} & \multicolumn{2}{|c|}{-0.21} & \multicolumn{2}{|c|}{0.29} & \multicolumn{2}{|c|}{0.23} & \multicolumn{2}{|c|}{0.31} & \multicolumn{2}{|c|}{0.61} \\
\hline Change, $\%$ & \multicolumn{2}{|c|}{$-5 \%$} & \multicolumn{2}{|c|}{$-6 \%$} & \multicolumn{2}{|c|}{$-6 \%$} & \multicolumn{2}{|c|}{$10 \%$} & \multicolumn{2}{|c|}{$9 \%$} & \multicolumn{2}{|c|}{$12 \%$} & \multicolumn{2}{|c|}{$26 \%$} \\
\hline P-value & \multicolumn{2}{|c|}{0.25} & \multicolumn{2}{|c|}{0.00} & \multicolumn{2}{|c|}{0.06} & \multicolumn{2}{|c|}{0.26} & \multicolumn{2}{|c|}{0.17} & \multicolumn{2}{|c|}{0.03} & \multicolumn{2}{|c|}{0.00} \\
\hline $\begin{array}{l}\text { Overall ranking in } \\
1997\end{array}$ & \multicolumn{2}{|l|}{1} & \multicolumn{2}{|l|}{2} & \multicolumn{2}{|l|}{3} & \multicolumn{2}{|l|}{4} & 5 & & 6 & & 7 & \\
\hline $\begin{array}{l}\text { Overall ranking in } \\
2017 \text { (same } \\
\text { products) }\end{array}$ & & 1 & & 2 & & 4 & & 3 & & 7 & & 6 & & 5 \\
\hline $\begin{array}{l}\text { Overall ranking in } \\
2017 \text { (all products) }\end{array}$ & & 2 & & 3 & & 8 & & 10 & & 12 & & 11 & & 9 \\
\hline
\end{tabular}

T-tests were conducted to determine whether changes over time in perceived quality based on COO were significant. Table 6 shows that the score for all eight product categories has improved for China in 2017 compared to 1997 ( $\mathrm{M}=2.94$ vs 2.33, $\mathrm{p}<0.00$ ), which supports Schniederjans et al. (2011). Perception towards products produced in Uzbekistan has significantly improved across most product categories investigated ( $\mathrm{M}=2.80$ vs $2.49, \mathrm{p}<0.03)$. The perception score for Turkey $(\mathrm{M}=3.22$ vs $2.93, \mathrm{p}<0.26)$, India $(\mathrm{M}=2.77$ vs $2.54, \mathrm{p}<0.17)$ and Russia $(\mathrm{M}=3.37$ vs $3.16, \mathrm{p}<0.06)$ has also increased but is insignificant for all three. Perception for USA $(\mathrm{M}=4.52$ vs $4.25, \mathrm{p}<0.00)$ has decreased by $6 \%$ and is statistically highly significant. The score has decreased for Japan $(-5 \%)$ but this is statistically insignificant $(\mathrm{M}=4.60$ vs 4.37 , $\mathrm{p}<0.25)$. Comparisons of mean scores of the variables and changes in the overall ranking of countries between 1997 and 2017 provides empirical support for H4.

\section{Conclusion}

The four hypotheses of this study have been upheld. Uzbek consumers still consider COO information an important cue when purchasing relatively expensive or symbolic products or those with a high risk of malfunctioning, suggesting that $\mathrm{COO}$ is particularly important for high-involvement products; the effect is present, but weaker where involvement is lower. Products from advanced countries such as Germany, Japan and the USA are perceived to have higher quality than those from less developed countries like India and China. These findings are in line with Zain and Yasin's (op.cit.) study, and support the assumption made by Ahmed et al. (2004) about the three main roles of COO information. According to Ahmed et al. (2004) COO is a separate informational cue, to indicate product quality, and to simplify the product evaluation process. Zain and Yasin (ibid) found that demographic factors had no significant effect on COO dimensions. By contrast, this study found that women are likely to be Social-Assurers and less concerned with price than men. For Security-Seekers, the difference is insignificant which means that security is equally important for men and women. Security seeking increases with age, while the need for social assurance and price vetting peak at age 46 to 55, perhaps because younger people tend to be less 
risk averse (El-Murad and West, 2003), whilst risk tolerance generally decreases with age (Yao, Sharpe and Wang, 2011). More Social-Assurers and Price-Vetters are married. Similar to Zain and Yasin (op.cit.), the level of education had no significant effect on importance of COO information. However, in contrast to Zain and Yasin's (op.cit.) findings, our results show that there is a significant difference between occupation and COO information dimensions. Security is most important for retired people.

The principal thrust of this study was to examine the consistency over time of customer attitude towards COO in a transitional economy. In Zain and Yasin's (op.cit.) study China had the lowest overall ranking. Twenty years later, the perception score for China has improved significantly, by $26 \%$ overall, to $5^{\text {th }}$ out of the original 7 countries for the original basket of goods, ahead of Uzbekistan and India, with products as different as shoes and cameras showing the greatest gains, and $9^{\text {th }}$ out 12 countries ahead of Turkey, Uzbekistan and India when the additional countries and the extended range of products are taken into account. The highest scoring Chinese products are cameras and electronic goods where they outscore Russia and Spain for some items. Perception towards the products produced in Uzbekistan has also slightly improved across all categories investigated, and by $12 \%$ overall. The main product categories where we can notice a significant increase in quality perceptions towards products made in Uzbekistan were cars, dresses and shirts. Meanwhile scores for some countries have decreased, notably for the USA $(-6 \%)$.

It can be concluded that the perception of quality in relation to $\mathrm{COO}$ is dynamic and developing countries may be able to improve consumer perception of and attitudes towards their national brands by pursuing appropriate strategies. It is worth noting Germany, the highest regarded COO in the present study, leads in only one category (cars), while Japan leads in eight. It may be that by specializing in their areas of strength transitional economies can more easily change their overall COO effect than by trying to excel at everything. Government officials and marketers should be concerned with how attitudes and beliefs about their country affect consumer and business decision-making. It is in the interest of both groups to strengthen their country's image to help domestic marketers to export their products, and to attract foreign investors. Similarly, companies and brand-owners wishing to exploit the developing markets of transitional economies such as Uzbekistan should play to their strengths: the present study showed the dominant position of Italy as a COO for clothing, of Japan for consumer electronics, and Germany for cars. Marketers from countries with no strong COO effect should be prepared to invest more in marketing communications and other brand-building strategies; this will not only help them to achieve sales in the short to medium term, but in the long term it will also help to change the image of their COO.

\section{References}

Agnoli, L., Capitello, R., De Salvo, M., Longo, A. and Boeri, M. (2016) "Food fraud and consumers' choices in the wake of the horsemeat scandal", British Food Journal, 118 (8), pp.1898-1913.

Ahmed, S.A. and d'Astous, A. (2008) "Antecedents, moderators and dimensions of country-of-origin evaluations", International Marketing Review, 25 (1), pp.75-106.

Ahmed, Z.U., Johnson, J.P., Yang, X., Kheng Fatt, C., Sack Teng, H. and Chee Boon, L. (2004) "Does country of origin matter for low-involvement products?" International Marketing Review, 21 (1), pp.102120.

Aichner, T., Forza, C. and Trentin, A. (2017) "The country-of-origin lie: impact of foreign branding on customers' willingness to buy and willingness to pay when the product's actual origin is disclosed", The International Review of Retail, Distribution and Consumer Research, 27 (1), pp.43-60.

Alexander, N., Doherty A-M., Carpenter J. and Moore, M. (2010) "Consumer receptiveness to international retail market entry", International Journal of Retail \& Distribution Management, 38 (3), pp.160-172.

Andéhn, M. and Decosta, P. (2016) "The variable nature of country-to-brand association and its impact on the strength of the country-of-origin effect", International Marketing Review, 33 (6), pp.851-866. 
Balabanis, G. and Diamantopoulos, A. (2011) "Gains and losses from the misperception of brand origin: The role of brand strength and country-of-origin image", Journal of International Marketing, 19 (2), pp.95-116.

Balcombe, K., Bradley, D., Fraser, I. and Hussein, M. (2016) "Consumer preferences regarding country of origin for multiple meat products", Food Policy, 64, pp.49-62.

Barbu, M. (2011) “The meanings of „made in Romania” among the Romanian consumers”, Theoretical and Applied Economics, 7(560) p. 31-42

Barbu, M. (2016) "the Romanian consumers living abroad - ambassadors of the Romanian brands?" Annals of 'Constantin Brancusi' University of Targu-Jiu. Economy Series. Issue 5, p67-71

Bello, D., Leung, K., Radebaugh, L., Tung, R.L. and Van Witteloostuijn, A. (2009) "From the editors: Student samples in international business research", Journal of International Business Studies, 40 (3), pp.361-364.

Bloemer, J., Brijs, K., Kasper, H., (2009) "The CoO-ELM model: a theoretical framework for the cognitive processes underlying country of origin-effects" European Journal of Marketing, 43 (1-2), pp. 62-89

Cagé, J. and Rouzet, D. (2015) "Improving "national brands": Reputation for quality and export promotion strategies", Journal of International Economics, 95 (2), pp.274-290.

Coulter, R., Price, L., Feick, L., and Micu, C. (2005) Journal of the Academy of Marketing Science. Fall, Vol. 33 Issue 4, p604-619.

Cui, P.A., Fitzgerald, P.M. and Donovan, R.K. (2014) "Extended self: implications for country-oforigin", Journal of Consumer Marketing, 31 (4), pp.312-321.

Diallo, M. F. and Cliquet, G. (2016) "Store image perceptions and customer knowledge cues in emerging markets: A cross-country investigation in Brazil and Vietnam", International Journal of Retail \& Distribution Management, 44 (12), 1182-1205.

Dinnie, K. (2004) “Country-of-origin 1965-2004: A literature review”, Journal of Customer Behaviour, 3 (2), pp.165-213.

El-Murad, J., and West, D. (2003) "Risk and Creativity in Advertising", Journal of Marketing Management, 19, 657-673

Huddleston, P., Good, L. K. and Stoel, L. (2001) "Consumer ethnocentrism, product necessity and Polish consumers' perceptions of quality”, International Journal of Retail \& Distribution Management, 29 (5), 236-246.

Insch, A. and Florek, M. (2009) "Prevalence of country of origin associations on the supermarket shelf", International Journal of Retail \& Distribution Management, 37 (5), 453-471.

Jeong, S., Stoel, L. and Chung, J. (2012) "Impacts of store type importance and country of origin: Exploring the case of dietary supplements in the Chinese market", International Journal of Retail \& Distribution Management, 40 (6), pp.471-487.

Johnson, Z.S., Tian, Y. and Lee, S. (2016) "Country-of-origin fit: When does a discrepancy between brand origin and country of manufacture reduce consumers' product evaluations?" Journal of Brand Management, 23 (4), pp.403-418.

Jones, M.Y., Vilches-Montero, S., Spence, M.T., Eroglu, S.A. and Machleit, K.A. (2010) "Do Australian and American consumers differ in their perceived shopping experiences? A bi-cultural analysis", International Journal of Retail \& Distribution Management, 38 (8), 578-596.

Kabadayi, S. and Lerman, D. (2011) "Made in China but sold at FAO Schwarz: country-of-origin effect and trusting beliefs", International Marketing Review, 28 (1), pp.102-126.

Kalicharan, H.D. (2014) "The effect and influence of country-of-origin on consumers' perception of product quality and purchasing intentions", The International Business \& Economics Research Journal, 13 (5), p.897.

Kan, G., Cliquet, G. and Gallo, P.M. (2014) "The effect of country image on hypermarket patronage intention: A cross-cultural study in China and Spain", International Journal of Retail \& Distribution Management, 42 (2), 106-130.

Kaynak, E. and Kara, A. (2002) "Consumer perceptions of foreign products: An analysis of productcountry images and ethnocentrism”, European Journal of Marketing, 36(7/8), pp.928-949. 
Koschate-Fischer, N., Diamantopoulos, A. and Oldenkotte, K. (2012) "Are consumers really willing to pay more for a favorable country image? A study of country-of-origin effects on willingness to pay”, Journal of International Marketing, 20 (1), pp.19-41.

Kumar, A., Kim, Y.K. and Pelton, L. (2009) "Indian consumers' purchase behavior toward US versus local brands", International Journal of Retail \& Distribution Management, 37 (6), 510-526.

Lampert, S., Jaffe E (1998) "A dynamic approach to country-of-origin effect", European Journal of Marketing, Vol. 32 Issue: 1/2, pp.61-78

Lascu, D.N. and Babb, H.W. (1995) "Market preferences in Poland: importance of product country-oforigin", Innovation, in Kaynak, E. and Eren, T. (Eds), Technology and Information Management for Global Development and Competitiveness, Istanbul, pp.216-22.

Leonidou, L.C., Hadjimarcou, J., Kaleka, A. and Stamenova, G.T. (1999) "Bulgarian consumers' perceptions of products made in Asia Pacific”, International Marketing Review, 16 (2), pp.126-142.

Loureiro, M.L. and Umberger, W.J. (2003) "Estimating consumer willingness to pay for country-oforigin labeling", Journal of Agricultural and Resource Economics, Vol.28, No.2 (August), pp.287-301.

Lu, I.R., Heslop, L.A., Thomas, D.R. and Kwan, E. (2016) “An examination of the status and evolution of country image research", International Marketing Review, 33 (6), pp.825-850.

Magnusson, P., Westjohn, S.A. and Zdravkovic, S. (2011) "What? I thought Samsung was Japanese: Accurate or not, perceived country of origin matters", International Marketing Review, 28 (5), pp.454472.

Maheswaran, D., Yi Chen, C. and He, J. (2013) "Nation equity: Integrating the multiple dimensions of country of origin effects", In Review of Marketing Research, Vol 5, pp. 153-189, Malhotra, N. Ed, Emerald Group Publishing Limited, ISBN 978-0-7656-2125-2.

Money, R., Colton, D., (2000) "The Response of the 'New Consumer' to Promotion in the Transition Economies of the Former Soviet Bloc" Journal of World Business. Summer, Vol. 35 Issue 2, p189-205

Nagashima, A. (1977) “A comparative "made in" product image survey among Japanese businessmen", The Journal of Marketing, Vol. 41, 3 (July) pp.95-100.

Nes, E.B., \& Bilkey, W.J. (1993) “A multi-cue test of country-of-origin theory” in: N. Papadopoulos\& L. Heslop (Eds). Product-Country Images: Impact and Role in International Marketing (179-185). New York, NY: International Business Press.

Niss, H. (1996) "Country of origin marketing over the product life cycle: A Danish case study”, European Journal of Marketing, 30 (3), pp.6-22.

Papadopoulos, N., Heslop, L.A. and Bamossy, G. (1990) "A comparative image analysis of domestic versus imported products”, International Journal of Research in Marketing, 7 (4), pp.283-294.

Papadopoulos, N. and Heslop, L.A. (2000) "A cross-national and longitudinal study of product-country images with a focus on the US and Japan”, Marketing Science Institute Report No. 00-106, Cambridge Massachusetts.

Rezvani, S., Dehkordi, G.J., Rahman, M.S., Fouladivanda, F., Habibi, M. and Eghtebasi, S. (2012) "A conceptual study on the country of origin effect on consumer purchase intention", Asian Social Science, 8 (12), p.205.

Samiee, S. (1994) "Customer evaluation of products in a global market", Journal of International Business Studies, 25 (3), pp.579-604.

Samiee, S., Leonidou, L.C., Aykol, B., Stöttinger, B. and Christodoulides, P. (2016) "Fifty years of empirical research on country-of-origin effects on consumer behavior: A meta-analysis", in Rediscovering the Essentiality of Marketing, pp. 505-510, Springer International Publishing.

Schniederjans, M., Qing, C., Schniederjans, D., and Ching Gu, V. (2011) Consumer Perceptions of Product Quality Revisited: Made in China, Quality Management Journal, 18 (3), 52-68.

Smith, S. (2015) "Made in America: A comparative perspective on country of origin labels for manufactured products in the United States and Canada", California Western International Law Journal, 45 (2), Art. 3, p.261. 
Tse, Y.K., Zhang, M., Doherty, B., Chappell, P. and Garnett, P. (2016) "Insight from the horsemeat scandal: Exploring the consumers' opinion of tweets toward Tesco", Industrial Management \& Data Systems, 116 (6), pp.1178-1200.

Usunier, J.C. (2006) "Relevance in business research: the case of country-of-origin research in marketing” European Management Review, 3, pp. 60-73

Usunier, J.C. (2011) "The shift from manufacturing to brand origin: suggestions for improving COO relevance", International Marketing Review, 28 (5), pp.486-496.

Wall, M., Liefeld, J. and Heslop, L.A. (1991) "Impact of country-of-origin cues on consumer judgments in multi-cue situations: a covariance analysis", Journal of the Academy of Marketing Science, 19 (2), pp.105-113.

Verlegh, P., Steenkamp, J., Meulenberg, M., "Country-of-origin effects in consumer processing of advertising claims" International Journal of Research in Marketing, 22 (2005), pp. 127-139

$\mathrm{Wu}$, J. and Fu, G. (2007) "The effects of brand origin country and made-in country on consumers' product evaluations and purchase intention", Frontiers of Business Research in China, 1 (3), pp.333-350.

Yao, R., Sharpe, D., Wang, F. (2011) "Decomposing the age effect on risk tolerance", The Journal of Socio Economics, 40, 6, 879-887

Zain, O.M. and Yasin, N.M. (1997) "The importance of country-of-origin information and perceived product quality in Uzbekistan”, International Journal of Retail \& Distribution Management, 25 (4), pp.138-145. 
Thank you very much for giving us the opportunity to revise our paper entitled "Does country-of-origin matter in the era of globalisation? Evidence from cross sectional data in Uzbekistan".

\section{Reviewers' Comments to Author:}

\section{Reviewer: 1}

\section{Recommendation: Accept}

\section{Comments:}

thanks for making the necessary revisions

\section{Additional Questions:}

$<b>1$. Originality: $</ b>$ Does the paper contain new and significant information adequate to justify publication?: yes

$<b>2$. Relationship to Literature: $</ b>$ Does the paper demonstrate an adequate understanding of the relevant literature in the field and cite an appropriate range of literature sources? Is any significant work ignored?: yes

$<b>3$. Methodology: $</ b>$ |s the paper's argument built on an appropriate base of theory, concepts, or other ideas? Has the research or equivalent intellectual work on which the paper is based been well designed? Are the methods employed appropriate?: yes

$<b>4$. Results: $</ b>$ Are results presented clearly and analysed appropriately? Do the conclusions adequately tie together the other elements of the paper?: yes

$<b>5$. Implications for research, practice and/or society: </b $>$ Does the paper identify clearly any implications for research, practice and/or society? Does the paper bridge the gap between theory and practice? How can the research be used in practice (economic and commercial impact), in teaching, to influence public policy, in research (contributing to the body of knowledge)? What is the impact upon society (influencing public attitudes, affecting quality of life)? Are these implications consistent with the findings and conclusions of the paper?: yes

$<b>6$. Quality of Communication: $</ b>$ Does the paper clearly express its case, measured against the technical language of the field and the expected knowledge of the journal's readership? Has attention been paid to the clarity of expression and readability, such as sentence structure, jargon use, acronyms, etc.: yes

All the comments of the Reviewer \#1 were positive.

We have made appropriate changes considering all comments of Reviewer \#2. Here is the detailed response to the reviewer's comments: 


\section{Reviewers' Comments to Author: Reviewer: 2}

\section{Recommendation: major revision}

\section{Reviewer's comment:}

$<b>1$. Originality: $</ b>$ Does the paper contain new and significant information adequate to justify publication?: The paper provides some new insights, but the authors need to elaborate what is new and why this study should be conducted in the introduction section. Why is this research worthy of study based on the research gaps?

\section{Author's response:}

Thank you for these observations and suggestions. We believe the paper does indeed contain new and significant information to justify publication. We have elaborated on these in the introduction section, following your suggestion.

\section{Reviewer's comment:}

$<b>1$. The strength of this paper is on investigating a dynamic aspect of COO effect. You need to elaborate it. Also, the authors need to explain why Uzbekistan is of a particular interest for the study. The authors need to provide a brief explanation how they examine the dynamic aspect of $\mathrm{COO}$ in the introduction so that readers can easily be guided.

\section{Author's response:}

Thank-you also for pointing out that a distinguishing feature of our study is the dynamic nature of COO; again, we have given added emphasis to this point in the introduction. Uzbekistan is of particular interest for several reasons: i) by conducting our research in the same country as the original study we were able to make a longitudinal comparison, ii) because it is a transition economy; the experience there may perhaps apply by extension to others, and iii) because it is the largest emerging market at the heart of Central Asia, likely to have an impact on the other countries in the region. This explanation has been added in the introduction, as has a brief explanation how we examined the dynamic aspect of $\mathrm{COO}$.

\section{Reviewer's comment:}

$<b>2$. Does the paper demonstrate an adequate understanding of the relevant literature in the field and cite an appropriate range of literature sources? Is any significant work ignored?

\section{Author's response:}

Yes, over fifty of the most important papers from a wide range of sources have been reviewed and cited. Nevertheless, we have gone back into the literature and added to this in the light of reviewers' comments.

\section{Reviewer's comment:}

$<b>2$. The authors explained COO well, but did not provide enough explanations of outcome variables investigated in the proposed hypotheses. The definitions or explanations of buyer perceptions, product evaluations, and perceived qualities?

\section{Author's response:}

We had to squeeze the paper shorter because of the word limit. Most of the reviewed papers do not provide definition for these outcome variables. However, considering the reviewer's comment we have added the following about the outcome 
variables: The outcome variables investigated in the proposed hypotheses such as buyer perceptions, product evaluations, and perceived qualities can be defined as follows. In this context buyer perception is the customer's impression about a brand or a company or its offerings. Evaluation means that product's suitability for use by consumers is assessed. Perceived quality can be defined as the customer's perception of the overall quality or superiority of a product relative to alternatives.

\section{Reviewer's comment:}

$<b>2$. The authors need to provide a rationale which tightly links the previous findings to the proposed hypotheses ( $\mathrm{H} 2$ and $\mathrm{H} 3$ ).

\section{Author's response:}

$\mathrm{H} 2$ states "attitude towards $\mathrm{COO}$ is related to consumers' (a) gender, (b) age, (c) marital status, (d) income and (e) education". The previous research found no significant difference with regard to $\mathrm{COO}$ attitude with regard to gender, marital status, and education (they did not report on age or income). The present study sought to establish whether or not this had changed. Age and income are widely acknowledged to have a role in consumer behaviour and therefore marketing so were added further to enrich this study for the benefit of future researchers. This could have been answered simply by performing ANOVA, but including it as a hypothesis to be tested ensured that data for all the required variables were collected.

H3 states "Perceived quality of products in relation to COO may change over time." At the time of the original study Uzbekistan had recently started to open up "to products from various countries" yet was still considered a country "where consumer experience with foreign products has been limited". Zain and Yasin (1997) did not seek to investigate the dynamic nature of COO effects; twenty years later it is important to examine the effects of this opening up and growing experience of foreign products in Uzbekistan; the present study builds on their cross-sectional findings - all of which link very tightly with our $\mathrm{H} 2$ and $\mathrm{H} 3$.

\section{Reviewer's comment:}

$<b>2$. Kaynak and Kara (2002) is relevant to H4?

\section{Author's response:}

Kaynak and Kara (2002) found that Turkish consumers' perceptions of products coming from different countries varied according to the level of socio-economic and technological development in those countries. Their excellent paper is indeed relevant to $\mathrm{H} 4$.

\section{Reviewer's comment:}

$<b>2$. Also, the specific interest of this research is Uzbekistan. There are some works of literature which discussed COO effect in the context of a transition economy or developing countries. If the specific interest is a transition economy, the authors need to explain about this in the introduction and provide some relevant literature reviews in the literature section.

\section{Author's response:}

We have explained above the reason for focusing on Uzbekistan and have addressed the issue of transition economies in the introduction; we have now discussed studies that specifically address $\mathrm{COO}$ issues in transition economies in the literature section. Thank you for these suggestions. 


\section{Reviewer's comment:}

$<b>2$. Check through the errors in the reference list.

Author's response:

The list of references has been checked and amended; thank you for pointing out the errors and omissions. It has now been corrected. All missing details have now been added; we apologise for the omissions.

\section{Reviewer's comment:}

$<b>3$. Methodology: $</ b>/$ s the paper's argument built on an appropriate base of theory, concepts, or other ideas? Has the research or equivalent intellectual work on which the paper is based been well designed? Are the methods employed appropriate?: Most of the sample is between their ages of 18 and 25. The authors asked questions about the mobile phones, personal computers/laptops, washing machines and air conditioners. How is this use of young population appropriate to answer the questions?

\section{Author's response:}

Authors of the original study suggested that "Future studies on country of origin should extend to other products" (p144). Our overall sample consisted of 527 people. 196 respondents were over 26 years old and 236 of them were employed. In Uzbekistan people get married from the age of 18 and by the time they reach their 25th year most families have at least 2 children. Considering this we can presume that most of these families are able to purchase mobile phones, personal computers/laptops, washing machines and air conditioners and are therefore appropriate research subjects for this study. In Zain and Yasin (1997) most of the respondents (more than 60\%) were between 18 and 34 years of age; this is not dissimilar to the sample in the present study.

\section{Reviewer's comment:}

$<b>3$. The authors suggested they selected these products based on the four focus group discussions. What are the characteristics of focus group participants? How was the discussion (interview?) conducted?

\section{Author's response:}

Thank you for your comment. Now we have extended this section by explaining the procedure of the focus group discussions. Four focus group discussions were conducted separately for male and female participants. Each group included up to eight people, mostly university colleagues and part-time graduate students. Trained research assistants moderated the process. Open-ended questions were used to identify the most popular product categories for which participants sought country-oforigin information.

\section{Reviewer's comment:}

$<b>3$. Also, you only included mobile phones, personal computers/laptops, washing machines and air conditioners? or added these to the previous questionnaires of Zain and Yasin (1997)?

\section{Author's response:}

We extended Zain and Yasin's questionnaire based on the focus group results by adding mobile phones, personal computers/laptops, washing machines and air conditioners (please refer to Table 5). We have elaborated this thoroughly in the methodology section. 


\section{Reviewer's comment:}

$<b>3$. Please elaborate the procedure of research and the measurement.

Author's response:

This section has been improved based on the reviewer's comments as follows: Section A of the questionnaire consisted of $13 \mathrm{COO}$ statements (please see Table 2), taken from Zain and Yasin's (1997) study, and measured the attitude of customers towards $\mathrm{COO}$ information of products. All measurement items pertained to five-point Likert-type scales ( $5=$ strongly agree; $4=$ agree; $3=$ neither agree nor disagree; 2 = disagree; and 1 = strongly disagree) and were adopted from recent relevant literature where they have repeatedly been shown to exhibit strong content validity (Zain \& Yasin, 1997).

Section B concerned the respondents' attitudes towards products made in specific countries. In this section, we asked respondents to evaluate perceived quality of specific products manufactured in given countries. The measurement composed of: "Please, evaluate (rate) the quality of products manufactured in the following countries" (please see Table 5). As this was asked and answered hypothetically (there being no foreign product or identifiable brand present to evaluate) answers to this question would actually reveal attitude towards a particular $\mathrm{COO}$ for a given product category. A five-point Likert-type scale was used to measure respondents' perceptions of quality for each product category from each country identified in the focus group, to indicate whether the overall evaluation of products is influenced by country stereotyping ( 5 = high quality, $4=$ somewhat high quality, $3=$ neither high nor low quality, 2 = somewhat low quality, 1 = low quality).

The final section of the questionnaire collected demographic information about the respondents. We calculated the average mean scores for perceived quality of products made in specific countries, conducted factor analysis to identify $\mathrm{COO}$ dimensions and ANOVA between demographic variables and COO importance. The perceived quality (the attitude towards $\mathrm{COO}$ ) for the different product categories is measured by one time in order to compare with the results of Zain and Yasin's 1997 study.

\section{Reviewer's comment:}

$<b>4$. Results: $</ b>$ Are results presented clearly and analysed appropriately? Do the conclusions adequately tie together the other elements of the paper?:

The research analysis should be consistent with the proposed hypotheses. The authors need to test the proposed hypotheses, but this paper seems like testing beyond their proposed relationships. Also, simply comparing mean scores of the variables do not provide any statistical implications, thus can not provide an empirical support of H3: Perceived quality of products in relation to COO may change over time.

\section{Author's response:}

Thank you for your comment. We have now conducted t-tests to analyse whether the perceived quality of products based on the country-of-origin may change over time. Table 6 shows that the perception score for eight product categories of China has improved in 2017 compared to 1997 ( $M=2.94$ vs 2.33, $p<0.00)$. Perception towards the products produced in Uzbekistan has also significantly improved across all product categories investigated ( $M=2.80$ vs $2.49, p<0.03$ ). Based on your suggestions we have improved the text and updated the tables. 


\section{Reviewer's comment:}

$<b>5$. Implications for research, practice and/or society: $</ b>$ Does the paper identify clearly any implications for research, practice and/or society? Does the paper bridge the gap between theory and practice? How can the research be used in practice (economic and commercial impact), in teaching, to influence public policy, in research (contributing to the body of knowledge)? What is the impact upon society (influencing public attitudes, affecting quality of life)? Are these implications consistent with the findings and conclusions of the paper?:

The authors need to provide an in-depth discussion based on the research findings. Please elaborate academic and managerial implications.

Author's response:

Managerial implications and contribution to (academic) knowledge have been mentioned in the introductory and concluding sections. These two sections have been elaborated based on the comments of the reviewer.

\section{Reviewer's comment:}

$<b>6$. Quality of Communication: $</ b>$ Does the paper clearly express its case, measured against the technical language of the field and the expected knowledge of the journal's readership? Has attention been paid to the clarity of expression and readability, such as sentence structure, jargon use, acronyms, etc.:

There are some grammatical errors in the manuscript. Please check if the paper is error-free.

\section{Author's response:}

Thank you for pointing this out. The paper has now been checked for grammatical, spelling and typographical errors and is now error-free.

We hope that these revisions meet your expectations. Should you need any further information, please do not hesitate to contact us.

Thank you! 